\title{
THE INFLUENCE OF FASHION STYLE ON INCREASING STUDENTS' INTERST IN LEARNING CLASS AT ELEMENTARY SCHOOL TEACHER EDUCATION (PGSD) STUDY PROGRAM QUALITY UNIVERSITY ACADEMIC YEAR 2017-2018
}

\author{
OLEH: \\ SITI RAKIYAH \\ (PGSD UNIVERSITAS QUALITY)
}

\begin{abstract}
The purpose of this study was to determine the effect of fashion styles on increasing student interest in learning at PGSD Study Program in Quality University. The method used in this research is descriptive method using a survey form. The subjects used were used students of PGSD Study Program at the University of Quality TA 2017/2018. The survey shows that the clothing styles used by students can affect their learning interest. They are more eager to go to college and go to class because one of them is the clothes they use are more contemporary, fashionable, and still new. However, it is not uncommon for students who wear clothes that are old fashioned in their interest to go to college less enthusiastic and often also have an impact on their activities in the classroom.
\end{abstract}

\section{Keywords: Fashion Style and Students' Interest}

\section{INTRODUCTION}

Interest is a powerful motivational process that energizes learning, guides academic and career trajectories, and is essential to academic success. Interest is both a psychological state of attention and affect toward a particular object or topic, and an enduring predisposition to reengage over time. Integrating these two definitions, the four-phase model of interest development guides interventions that promote interest and capitalize on existing interests. Four interest-enhancing interventions seem useful: attention-getting settings, contexts evoking prior individual interest, problem-based learning, and enhancing utility value. Promoting interest can contribute to a more engaged, motivated, learning experience for students. ${ }^{1}$

\footnotetext{
${ }^{1}$ Judith M. Harackiewicz, Jessi L. Smith, and Stacy J. Priniski. 2018. Interest Matters: The Importance of Promoting Interest in Education. Policy Insights Behav Brain Sci. 2016 Oct; 3(2): 220-227. Published online 2016 Jun 30. doi: $\underline{10.1177 / 2372732216655542}$
} 
Whether it be a "race to the top" or "no child left behind" or "every student succeeds," U.S. educational policies focus on elevating students' performance, with much less focus on sustaining students' interest. Yet, when students are interested in an academic topic, they are more likely to go to class, pay attention, become engaged, take more courses, as well as process information effectively and ultimately perform well. ${ }^{2}$ Students who discover academic interests in high school and college are better prepared for satisfying careers. Fashion is a popular aesthetic expression in a certain time and context, especially in clothing, footwear, lifestyle, accessories, makeup, hairstyle and body proportions. ${ }^{3}$ If the instructors have ever watched the rehearsal process of a play, then the instructors know just how powerful clothes are. Even in the very early stages of a project, professional actors will come to practice in certain clothing pieces that make them feel more like their character. Perhaps it's an old pair of shoes, a long and heavy skirt, or a bandana that helps them get just the right swagger, grace, or edge, this condition also happens with our students not only in the film but also in the college. Can fashion style help students harness this motivation and thus help students develop interest in learning?

\section{Review Of Literature}

Clothing has the effect for the students in learning process. Clothing is not simply a private or personal matter; it implies the existence of an intersubjective social world in which one presents oneself and is seen by others. In examining the implications of fashion for students interest. Fashion aggravates antagonistic relationship among students when it is used to flaunt one's status and wealth, but clothes can also be used to exhibit respect toward others and allegiance to a group. Clothes, therefore, sometimes facilitate the students of widely distributed power

\footnotetext{
${ }^{2}$ Hidi S, Harackiewicz JM. Motivating the academically unmotivated: A critical issue for the 21st century. Review of Educational Research. 2000;79:151-179. doi: 10.2307/1170660. [CrossRef] [Google Scholar]
}

${ }^{3}$ Kaiser, Susan. B. (2019). Fashion and Cuitural Studies. Bloomsbury Visual Arts. ISBN $\underline{978-}$ $\underline{1350109605}$. OCLC $\underline{1057778310}$. 
or interest in the class. When fashion manifests creativity, respect, allegiance, or membership, the relationships that it fosters are potentially students interest. ${ }^{4}$

Dressing smart is also important for students'confidence and sense of selfempowerment. But students'style do more than just send messages, to students'mind or to others. New research shows it actually impacts how we think. Professional dress, one study found, increases abstract thinking and gives people a broader perspective. So that tie might actually be switching on students'creativity button. "The formality of clothing might not only influence the way others perceive a person, and how people perceive themselves, but could influence decision making in important ways through its influence on processing style," the study says. Professional attire creates social distance. When we are more socially distant, we tend to think in more distant, abstract terms. In socially distant settings we address people by their title, for instance, rather than the more intimate first name. Even after controlling for socioeconomic status, students wearing more formal clothing showed stronger inclinations towards abstract processing. ${ }^{5}$ students who can use good clothes in class can also increase their interest in learning and high self-esteem both when interacting in class and outside the classroom. Dress practices throughout history were developed for three primary reasons: protection, modesty, and decoration or ornamentation. ${ }^{678}$ Dress may serve as the need for adornment, for modesty, or for protection, or all of these in varying measures.

Clothing also serves to communicate membership of a cultural group both to those who are members of it and those who are not. It is a social process that creates cultural meaning and is a fundamental part of our communication in social interactions. Clothing has been creatively described as the second skin $^{9}$ and the

\footnotetext{
${ }^{4}$ Joshua I. Miller. 2005. Fashion and Democratic Relationships. The University of Chicago Press on behalf of the Northeastern Political Science Association

${ }^{5}$ Molly St. Louis. 2017. Research Shows That the Clothes You Wear Actually Change the Way You Perform. Inc. Manuseto Ventures.

${ }^{6}$ Flugel, J. C. (1930). The psychology of clothes. New York: International Universities Press

${ }^{7}$ Horn, M. J., \& Gurel, L. M. (1981). The second skin. Boston: Houghton Mifflin.

${ }^{8}$ Ross, R. (2008). Clothing: A global history. Maldon, MA: Policy Press

${ }^{9}$ Horn, M. J., \& Gurel, L. M. (1981). The second skin. Boston: Houghton Mifflin.
} 
visible self.${ }^{10}{ }^{11}$ As humans we communicate a great deal about ourselves through our personal style and dress. Fashion is a symbolic production that differs from the concept of clothing. Fashion merges us with our emotional needs, and it expresses our inner individual personality by external marks and symbols, brands, and status items. ${ }^{12}$ The symbolic nature of clothing can incorporate styles, brands, retailer outlets, uniforms, and also membership to certain subcultures. The meanings that these produce can contribute to an individual's sense of who they actually are. Fashion affect's both our self-concepts and our internal feelings (Tombs, 2010). ${ }^{13}$

\section{RESEARCH METHOD}

This study was conducted to investigate contemporary effects of students attire (specifically, graduate teaching assistant attire) on students' perceptions of college teachers in a live lecture context. Effects of three dress conditions, formal professional, casual professional, and casual, were tested under tightly controlled experimental conditions. Like it or not, students'clothes and presentation communicate volumes about student as a person. The question is not whether students care about fashion, it's more about what the students are communicating intentionally or unconsciously through their fashion choices.

\section{RESULT}

Results indicated that more formal dress (business suits, dress shoes) was associated with increased ratings of students competence, particularly for female students rating female instructors. However, contrary to common assumptions, the most positive influences of students dress were found in the highly casual condition (faded jeans, T-shirt, flannel shirt). Perceptions of homophily accounted for a small amount of variance in students ratings, but there was no significant effect of dress condition on ratings of homophily. Overall findings suggest that

\footnotetext{
${ }^{10}$ Eicher, J. B., Evenson, S. L., \& Lutz, H. A. (2008). The Visible Self (3rd ed.). New York: Fairchild.

${ }^{11}$ Roach, M., Eicher, J. (1973). The Visible Self: Perspectives on Dress. New York: The Macmillan Company.

${ }^{12}$ Kaiser, Susan. B. (2019). Fashion and Cuitural Studies. Bloomsbury Visual Arts. ISBN 9781350109605. OCLC 1057778310.

${ }^{13}$ Tombs, A. (2010). Do our feelings leak through the clothes we wear? Australian \& New Zealand Marking Academy.
} 
caution be used in drawing conclusions regarding potential payoffs of professional classroom dress based upon literature not specifically concerned with the classroom context. Students in Elementary School Teacher Education Study Program at Quality University for the 2017-2018 academic year are clearly marked the difference between students who wear good clothes and students who don't wear good clothes. For students who use good clothes, their confidence is greater when interacting in class and outside the classroom. They are more active in learning in class and more cheerful in their faces compared to students who do not use good clothes. They are very active in interacting in class because many of their friends pay attention to their appearance so that their other friends are interested in listening to their explanations. Therefore high self-esteem arises, and ultimately their learning interest increases and their learning outcomes increase because they become diligent in learning.

\section{COBCLUSION AND SUGGESTION}

Based on the results of the above data we can conclude that the clothes worn by students can determine their learning interest and can even improve their learning outcomes. If they wear good clothes they can increase their interest in learning and their learning outcomes and can also improve their self-esteem for the better. Therefore, it is expected that the lecturers at the first meeting at the beginning of the lecture should give instructions to all students to use good and beautiful clothes to create comfort during the teaching and learning process, but if the student does not have good clothes, but at least they are advised to use neat clothes and keep using fragrances because everyone's economic condition is different.

\section{REFERENCES}

Eicher, J. B., Evenson, S. L., \& Lutz, H. A. (2008). The Visible Self (3rd ed.). New York: Fairchild.

Flugel, J. C. (1930). The psychology of clothes. New York: International Universities Press

Hidi S, Harackiewicz JM. Motivating the academically unmotivated: A critical issue for the 21st century. Review of Educational Research. 2000;79:151179. doi: 10.2307/1170660. [CrossRef] [Google Scholar] 
Horn, M. J., \& Gurel, L. M. (1981). The second skin. Boston: Houghton Mifflin.

Judith M. Harackiewicz, Jessi L. Smith, and Stacy J. Priniski. 2018. Interest Matters: The Importance of Promoting Interest in Education. Policy Insights Behav Brain Sci. 2016 Oct; 3(2): 220-227. Published online 2016 Jun 30. doi: 10.1177/2372732216655542

Joshua I. Miller. 2005. Fashion and Democratic Relationships. The University of Chicago Press on behalf of the Northeastern Political Science Association

Kaiser, Susan. B. (2019). Fashion and Cuitural Studies. Bloomsbury Visual Arts. ISBN 978-1350109605. OCLC 1057778310.

Molly St. Louis. 2017. Research Shows That the Clothes You Wear Actually Change the Way You Perform. Inc. Manuseto Ventures.

Roach, M., Eicher, J. (1973). The Visible Self: Perspectives on Dress. New York: The Macmillan Company.

Ross, R. (2008). Clothing: A global history. Maldon, MA: Policy Press

Tombs, A. (2010). Do our feelings leak through the clothes we wear? Australian \& New Zealand Marking Academy. 